\title{
6. Nemzetközi Hálózati Tanulási Konferencia
}

Így hivatkozzon erre a cikkre:

Pintér Róbert. „6. Nemzetközi Hálózati Tanulási Konferencia”.

Információs Társadalom VIII, 3. szám (2008): 143-147.

A folyóiratban közölt müvek

a Creative Commons Nevezd meg! - Ne add el! - Így add tovább! 4.0

Nemzetközi Licenc feltételeinek megfelelően használhatók. 
Pintér Róbert

\title{
Konferenciabeszámoló
}

\author{
6. Nemzetközi Hálózati Tanulási Konferencia \\ (6th International Conference on Networked Learning) \\ Halkidikí, Görögország \\ 2008. május 5-6.
}

\section{Bevezetés: hálózati tanulás először a Brit-szigeteken kívïl}

2008-ban, május elején, a „konferenciaturizmus” főidényében rendezték meg a 6. Nemzetközi Hálózati Tanulási Konferenciát (6th International Conference on Networked Learning-NLC) a festối szépségú Halkidiki-félsziget egy tengerparti szállodájában, Görögországban. A kétévente sorra kerülố rendezvény tízéves története során először mozdult ki Nagy-Britanniából, a helyszínen ennek ellenére is erősen érzôdött az angolszász dominancia, amit a szervezô görögök meghatározó jelenléte sem tudott elhomályosítani.

Magyarországot a NETIS (Network for Teaching Information Society) projekt képviselte, jómagam a Budapesti Múszaki és Gazdaságtudományi Egyetemen múködő Információs Társadalom- és Trendkutató Egyetem színeiben vettem részt a konferencián, míg Bessenyei István a Web 2.0 oktatási szakértôjeként a soproni Nyugatmagyarországi Egyetem jó hírét öregbítette.

A programban 3 előadás, 14 szimpózium és 53 prezentáció szerepelt, mindössze két napba súrítve. Mindezt úgy sikerült megvalósítaniuk a rendezóknek, hogy egyszerre öt (!) teremben folyt párhuzamosan a program, így meglehetốsen nagy versengés folyt a figyelemért, miközben folyamatosan jöttek-mentek a résztvevók, hogy elcsípjék egy-egy panel izgalmasabb előadásait. De ha valaki mégis lemaradt volna valamiról, nem kellett aggódnia, a konferenciacsomagba bekészített kiadványban minden elốadás egyoldalas kivonata megtalálható volt, emellett hordozható kis USB-kulcson minden résztvevő elôre megkapta az összes előadás tanulmányváltozatát, absztraktját és a panelek leírását (vélhetôen késóbbi, otthoni olvasásra).

Egy ilyen konferencia természetesen nemcsak az előadások meghallgatására vagy a helyszín nyújtotta kikapcsolódásra alkalmas, hanem kapcsolatépítésre, az azonos vagy közel azonos problémákon dolgozó kutatók közötti vitára is, így a kávészünetekben és esténként, vacsora közben igen élénk eszmecsere folyt a résztvevók között.

\section{Röviden a hálózati tanulásról}

A hálózati tanulás (networked learning) viszonylag új koncepció: a 90-es években terjedt el az a felismerés a pedagógusok és oktatáskutatók körében, hogy a tanulás elsôsorban nem individuális, hanem közösségi tevékenység, a tanulás folyamatában a közösségek, a részvétel, az együttmúködés, a közös munka a meghatározó, nem pedig az 
egyéni aktivitás. Az új kommunikációs eszközök - mint amilyen az internet - csak felerôsítették ezt a trendet, a hálózati tanulás esetében azonban nem maguk a hálózati kommunikációs technológiák állnak a fókuszban, hanem a közösségek, hálózatok értékelődnek fel.

Brit, amerikai és nyugat-európai kutatók több mint tíz éve kutatják ezt a jelenséget. Eközben a területnek saját szakzsargonja alakult ki, több folyóiratot is megjelentetnek. Mindez azt is jelenti, hogy a hálózati tanulás - bár kívülról úgy túnhet - nem feleltethetố meg teljes egészében a számítógéppel segített tanulásnak (computer assisted learning), az elektronikus tanulásnak (e-learning) vagy az élethossziglani tanulásnak (lifelong-learning), vagyis itt nem egyszerúen egy új kifejezésrốl, hanem egy új nézópont meghatározóvá válásáról van szó.

\section{Szubjektív élménybeszámoló}

Természetesen mindazt, ami egy ilyen konferencián elhangzik, nem lehet egy rövid beszámoló keretében összefoglalni, már csak azért sem, mert egyetlen ember kevés, hogy a párhuzamosan zajló előadások mindegyikét figyelemmel kísérje. A konferenciákon való részvétel - a látszattal ellentétben - nagyon szubjektív „múfaj”, mindenki egyéni programot állít össze magának, és egyéni módon vonja le a tanulságokat. Emiatt ez a konferenciabeszámoló is vállaltan szubjektív: az alábbiakban néhány számomra izgalmas elôadásból szemezgetek, bízva abban, hogy az így kiragadott gondolatok mások számára is elgondolkodatónak bizonyulnak.

\section{Infokommunikáció és társadalmi igazságosság}

A megnyitó elôadás meglehetôsen sokkolónak bizonyult. Charalambos Vrasidas, a CARDET (Centre for the Advancement of Research \& Development in Educational Technology ${ }^{1}$ ) ügyvezetôje és az UNESCO International Council of Educational Media végrehajtó bizottságának tagja a harmadik világ nyomorát, kiszolgáltatottságát bemutató képekkel arra ébresztette rá a hallgatóságot, hogy a Thomas L. Friedman hirdette tézissel ellentétben a világ nem lapos, sokan kizáródnak a termelési és fogyasztási rendszerekból. Pedig statisztikai adatok szerint ötévnyi oktatás elég ahhoz, hogy valaki kitörjön a szegénység újratermelődésének, átörökítésének csapdájából. Hogy megértsük, milyen lemaradásról van szó a harmadik világ esetében, Vrasidas két képet mutatott be: az egyiken egy száz évvel ezelótti nyugati fiúiskolát láthattunk, a másikon pedig egy fejlődő országbeli mai iskolát. Az elmúlt száz évben szinte semmi sem változott: a puritán osztályteremben padokban ülnek a diákok frontális elrendezésben (tanárral és táblával szemben).

Ez a kép azonban nemcsak a fejlődố világ lemaradására mutatott rá, hanem arra is, hogy az oktatás nem tartott lépést a világgal. A bemutatott képen a technológiának nyo-

${ }^{1}$ Lásd http://www.cardet.org/. A CARDET nemzetközi nonprofit, nem kormányzati kutatási és fejlesztési intézmény. 
ma sincs, a tábla és a könyv a két legfontosabb tanulási eszköz - és ez még szerencsés, mert sok helyen se könyv, se tábla nincs. Az előadó véleménye szerint pedig addig nem is tör be a technológia az osztálytermekbe, és nem lesz hálózati tanulás (nem változik a tudásátadás szerkezete), amíg a tanár feladata elsốsorban az, hogy felkészítse a diákokat a vizsgákra, hogy jobb egyetemekre kerülhessenek, és azután jobb állást kapjanak, sígy jobb életet élhessenek - szemben azokkal, akiknek ez nem sikerül. Az iskolai oktatás tehát - tehetnénk hozzá - ma nem a tudás átadásáról szól, hanem a társadalmi egyenlốtlenségek újratermelődéséról.

Ahhoz, hogy ezen változtatni lehessen, új eszközökre van szükség, például játékokra. Ez „cool” a diákok szemében, ugyanakkor hasznos is lehet (interaktív, lehetôséget ad a visszajelzésre, egyszerre több érzékszervre hat, kreatív stb.). Vrasidas be is mutatott egy ilyen játékot, ahol a segélyezés, élelmezés dilemmáival ismerkedhettek meg virtuális küldetések során a játékos diákok. A játék részét képezte, hogy össze kellett állítani az élelmiszercsomagokat (figyelve arra, hogy a területen lakóknak milyen tápanyagokra, mennyi kalóriára, vitaminra stb. van szükségük), ki kellett választani azokat a területeket, ahová helikopterrel biztonságosan ledobhatók a csomagok, majd el kellett juttatni azokat a célba.

Végezetül egy újabb képpel zárt az elóadó, amelyen az informális tanulás került a középpontba: ez azért fontos, mert iskolák csak néhány száz éve léteznek, a tanulás, az informális tudásátadás viszont több százezer éves múltra tekint vissza. Az emberek élnek, és közben (észrevétlenül) tanulnak. A tanulás ugyanis az értelemadás folyamata, mindig tanulunk, ami nem lehet pusztán formális, intézménybe zárt. Mindezek miatt az előadó bizakodását fejezte ki a jövớvel kapcsolatban, amiben feltehetốen több lesz a hálózati tanulás is.

\section{Hol van a tanulás a hálózati tanulásban?}

Számomra a konferencia egyik legfontosabb kérdését a Vivien Hodgson (Department of Management Learning and Leadership, Lancaster University) által szervezett szimpózium fogalmazta meg, amely bevezette a hallgatóságot a hálózati tanulás paradigmájába, miközben nem az egyébként többnyire fókuszban levő hálózatisággal foglalkozott, hanem a tanulást állította a középpontba kérdésével, hogy hol van a tanulás a hálózati tanulásban. A hálózati tanulás Hodgson szerint ugyanis azt jelenti, hogy a tanulásban részt vevók közötti kommunikáció kiemelten fontos. A helyzet és a pedagógus segíti a tanulók közötti együttmúködést, és (az osztálytermen kívül) infokommunikációs eszközök is rendelkezésre állnak az interakció biztosítására.

Maria Zenios (CSALT/ Educational Research, Lancaster University) - a szimpózium elsô előadója - azt emelte ki, hogy a kollaboratív tudásmegosztásban kiemelten fontos a folyamatos kommunikáció, a kitartó, pontos vita egy adott kérdés körül. A pedagógusnak nem kész (lexikális) válaszokat kell adnia egy kérdésre, hanem segítenie kell a diákokat, hogy maguk válaszoljanak a saját kérdéseikre, hogy megtalálják a megfelelő forrásokat, további kérdéseket tudjanak megfogalmazni, ki tudják alakítani saját álláspontjukat, legyen véleményük, érvelni tudjanak a véleményük mellett, és ugyanakkor legyenek észérvek által meggyớzhetôk. A mai pedagógusok gyakorta kész vála- 
szokkal szolgálnak a diákoknak, így azok számára elvész a felfedezés lehetôsége, hogy önmaguk ismerhessenek meg egy területet, egy problémát, vagy hogy saját kiinduló kérdéseik lehessenek.

Chris Jones (Institute of Educational Technology, Open University) egy klasszikus filozófiai-pedagógiai kérdést vetett fel, ami a hálózati tanulás számára az egyik meghatározó kérdést jelenti. Ez pedig az, hogy mit gondolunk, hol, milyen formában zajlik a tanulás? Az egyénben (a személy fejében megy végbe minden - ami igen gyakori feltételezés), vagy társas folyamatok révén? A hálózati tanulás irányzata inkább a második mellett foglal állást. Jones a következóket emelte ki a hálózati tanulás sajátosságaiként:

- lehet aszinkron (nem egy idóben zajlik, mint például az osztálytermi tanulás),

- térben, fizikailag szétszórtak lehetnek a résztvevôii,

- nagyon fontos, hogy az aktivitások digitálisan megốrzôdnek, késóbb visszakereshetók, újra felhasználhatók,

- szemben a hagyományos tanulással, folyamatos az „átjárás” a privát és a publikus szféra között,

- sokszínú, az (új) írásbeliség új formái próbálhatók ki benne (például blog, wiki, multimédia).

Mindez azonban felveti bennem a kérdést, hogy hogyan valósítható meg a hálózati tanulás hagyományos osztálytermi intézményi környezetben, az ahhoz szabott tanmenet, oktatási kultúra és mind a tanulók, mind a szülók effajta oktatásra vonatkozó elvárásai mellett.

A hálózati tanulás természetesen nemcsak iskolai közegben értelmezhetô. Thomas Ryberg (Department of Communication and Psychology, Aalborg University) egy konkrét projekt kapcsán azt mutatta be, hogy egy két és fél napos workshop folyamán honnan jönnek az ötletek, a gondolatok, és ezek hogyan reflektálódnak egymásra, hogyan kapcsolódnak össze egy hálózatban. Hasonlata szerint az így megszületố eredmények sokkalta inkább egy hatalmas patchworkre ${ }^{2}$ mutatnak, mintsem jól átgondolt, egyénekhez köthetố tiszta koncepciókra. Ryberg ily módon egy szakértói közösség bemutatása révén a hálózati tanulás osztálytermen kívüli értelmezésére mutatott megoldást.

\section{Befejezés: a részvétel zsarnoksága}

Végül hadd emeljem ki Debra Ferreday (Lancaster University) szavait, aki szerint a hálózati tanulás lényege ,a részvétel és együttmúködés zsarnoksága a csoport és a módszer zsarnoksága felett”. A hálózati tanulásban arra kell törekedni, hogy ne a csoport, illetve a követett pedagógiai módszer határozza meg a tanulást, hanem minden a részvételnek és az együttmúködésnek legyen alárendelve, az határozza meg a csoport tagjainak életét. Aki a hálózati tanulást választja (akár tanárként, akár diákként), annak tisztában kell lennie azzal, hogy itt minden a részvételtól, az együttmúködéstól és a

\footnotetext{
${ }^{2}$ Erról én az apró szövetdarabokból összevarrt patchwork takaróra asszociálok, amely tulajdonképpen egyetlen takaró, mégis jól látni, hogy egymástól korábban idegen anyagdarabok együttese alkotja.
} 
kommunikációtól függ. A csoport tagjai akkor tanulnak a legtöbbet, ha mindannyian a lehetố legaktívabban részt vesznek a közös tanulási folyamatban, miközben hagyják a másikat is szóhoz jutni... Legtöbbször pedig éppen a részvétel jelenti a legnagyobb problémát: Hogyan lehet fenntartani és egyensúlyban tartani a részvételt és együttmúködést úgy, hogy a csoport tudása növekedjen, és az egyes egyének motivációja is fennmaradjon?.

A konferencia anyagai (absztraktok, teljes tanulmányok) hozzáférhetók az interneten is: http://www.networkedlearningconference.org.uk/ 